\title{
The cyanogenic polymorphism in Trifolium repens L. (white clover)
}

\author{
M. A. HUGHES \\ Department of Biochemistry and Genetics, The Medical School, The University, Newcastle upon Tyne NE2 4HH
}

\begin{abstract}
The cyanogenic polymorphism in white clover is controlled by alleles of two independently segregating loci. Biochemical studies have shown that non-functional alleles of the $A c$ locus, which controls the level of cyanoglucoside produced in leaf tissue, result in the loss of several steps in the biosynthetic pathway. Alleles of the $L i$ locus control the synthesis of the hydrolytic enzyme, linamarase, which is responsible for $\mathrm{HCN}$ release following tissue damage. Studies on the selective forces and the distribution of the cyanogenic morphs of white clover are discussed in relation to the quantitative variation in cyanogenesis revealed by biochemical studies. Molecular studies reveal considerable restriction fragment length polymorphism for linamarase homologous genes.
\end{abstract}

Keywords: cyanogenesis, polymorphism, Trifolium repens, white clover.

\section{Introduction}

The term cyanogenesis describes the release of hydrocyanic acid $(\mathrm{HCN})$, which occurs when the tissues of some plant species are damaged. The first report of cyanogenesis in Trifolium repens (white clover) was by Mirande (1912) and this was shortly followed by a paper which demonstrated that the species was polymorphic for the character, with both cyanogenic and acyanogenic plants occurring in the same population (Armstrong et al., 1913). Since these reports, this polymorphism has been the subject of a large number of ecological studies. Field studies, dating back to 1954, have investigated the distribution of the two morphs and both field and experimental studies have investigated the nature of the selective forces responsible for maintaining the polymorphism in this species. This experimental system provides one of the few examples of a simply inherited, biochemical difference that is known in higher plants. Modified dihybrid Mendelian segregation ratios, in progeny scored for the production of $\mathrm{HCN}$, were demonstrated in the 1940s. More recently the morphs have been characterized biochemically and molecular studies, which will elucidate the nature of the allelic differences responsible for the polymorphism, are in progress. These studies provide information at the molecular level about genetic differences which have been subject to selection and which may be complex.

The cyanogenic polymorphism in white clover is thus the subject of studies that range from molecular genetics to plant taxomony. This review discusses the extensive and diverse ecological genetic studies in relation to the more recent biochemical and molecular studies of cyanogenesis in white clover.

\section{Biochemistry}

The production of $\mathrm{HCN}$ by higher plants depends upon the co-occurrence of a cyanogenic glycoside and catabolic enzymes. In white clover, two related cyanoglucosides are produced, 1-cyano-1-methylethyl $\beta$-Dglucopyranoside (linamarin) and R-1-cyano-1-methylpropyl $\beta$-D-glucopyranoside (lotaustralin). These cyanoglucosides are also found in cassava (Manihot esculenta Cranz), flax (Linum usitatissimum L.), rubber (Hevea braziliensis L. Muell.-Arg.), lima bean (Phaseolus lunatus L.) and bird's-foot trefoil (Lotus corniculatus L.).

The primary precursors of all plant cyanoglycosides investigated are restricted to the five hydrophobic protein amino acids and one non-protein amino acid. In white clover, the amino acids, valine and isoleucine, are precursors of the two related cyanoglucosides. The biosynthetic pathway (Fig. 1) follows the general pattern found for all cyanoglucosides studied (Hughes \& Conn, 1976; Collinge \& Hughes, 1982a). The steps from amino acid to hydroxynitrile are carried out by a microsomal system and are metabolically channelled, whereas the last step is carried out by a soluble enzyme, UDP-glucosyltransferase (Hahlbrock \& Conn, 1971). Recent work by Halkier et al. (1989) has shown 
that the pathway shown in Fig. 1 must be modified for cyanoglucoside biosynthesis in sorghum, and this demonstration of further steps in the sorghum pathway indicates the existence of similar steps in other species.

In white clover, one set of microsomal enzymes is responsible for the biosynthesis of both hydroxynitrile intermediates from the amino acid precursors, valine and isoleucine (Collinge \& Hughes, 1984). It has also been demonstrated that, in flax, one soluble glycosyltransferase is responsible for the production of both glucosides (Hahlbrock \& Conn, 1971).

In general, cyanogenic glucosides are broken down by sequential hydrolysis (Poulton, 1988). Firstly, a $\beta$-glucosidase (linamarase) cleaves off the glucose residue, the two hydroxynitriles produced in white clover are unstable at high $\mathrm{pH}$, but an $\alpha$-hydroxynitrile lyase has been characterized from cassava which breaks the hydroxynitriles down to $\mathrm{HCN}$ and a ketone

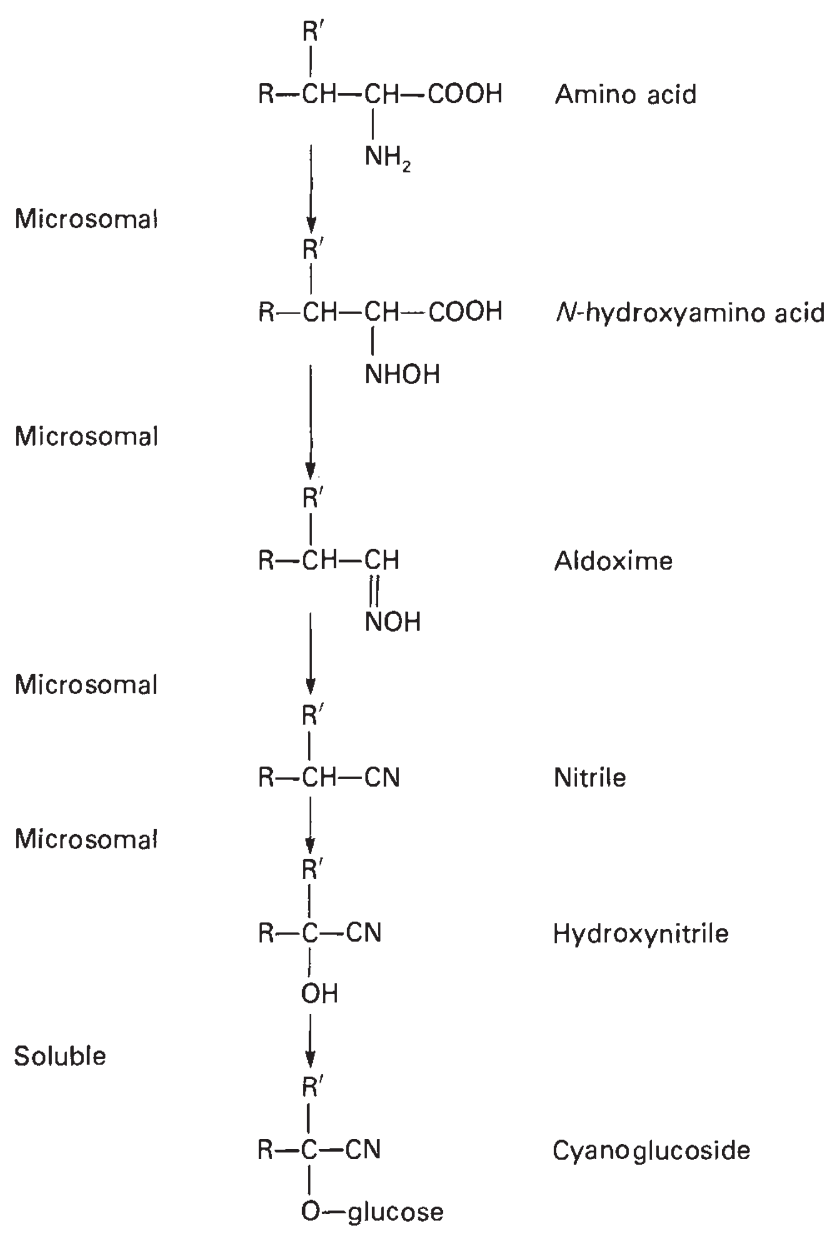

Fig. 1 The pathway for the biosynthesis of the cyanogenic glucosides, linamarin and lotaustralin (after Hughes \& Conn, 1976); $\mathrm{R}=\mathrm{CH}_{3}, \mathrm{R}^{\prime}=\mathrm{CH}_{3}$ valine and linamarin; $\mathrm{R}=\mathrm{CH}_{3}$, $\mathrm{R}^{\prime}=\mathrm{C}_{2} \mathrm{H}_{5}$ isoleucine and lotaustralin.

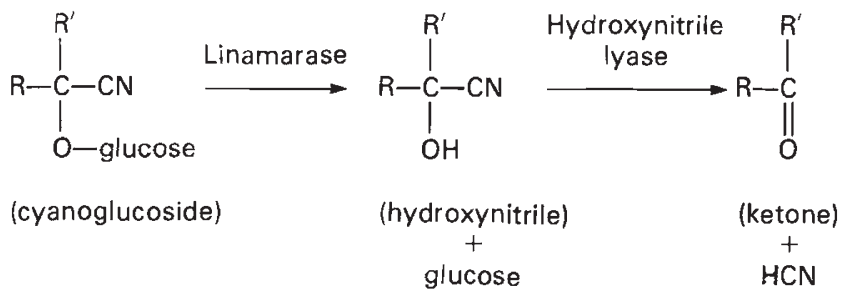

Fig. 2 The hydrolytic release of $\mathrm{HCN}$ from the cyanoglucosides; $\mathrm{R}=\mathrm{CH}_{3}, \mathrm{R}^{\prime}=\mathrm{CH}_{3}$ linamarin; $\mathrm{R}=\mathrm{CH}_{3}$, $\mathrm{R}^{\prime}=\mathrm{C}_{2} \mathrm{H}_{5}$ lotaustralin.

(Fig. 2). There is one report of hydroxynitrilase activity in white clover (Carvalho, 1981) but the enzyme has not been studied in detail. The importance of hydroxynitrilase activity for rapid $\mathrm{HCN}$ production has, however, been shown in Hevea brasiliensis (Selmar et al., 1989).

The cyanogenic $\beta$-glucosidase (linamarase) of white clover is a homodimer with a subunit molecular mass of $62,000 M_{\mathrm{r}}$. It is the major soluble high-mannose asparagine-linked glycoprotein in young leaves, where it can represent up to 5 per cent of the total soluble protein (Hughes \& Dunn, 1982). The antibiotic, tunicamycin, prevents linamarase synthesis but no precursor polypeptides have been found in vivo. In vitro translation of young leaf mRNA produces a major $59,000 M_{\mathrm{r}}$ polypeptide, which is recognized by affinity-purified linamarase antibodies and processed by dog pancreas microsomes to a $62,000 M_{\mathrm{r}}$ protein (Dunn et al., 1988). Although the glycosylation of linamarase is clearly demonstrated by these results, the possibility of proteolytic processing remains unresolved.

Kinetic studies show that linamarase will hydrolyse a number of synthetic glycosides and that the carbohydrate moiety of each substrate attaches to the same binding site at the active centre (Pocsi et al., 1989). It is the aglycone and the angular arrangement around the glycosidic linkage which are the major determinants in substrate specificity.

\section{Developmental physiology}

In white clover both the cyanogenic glucosides and linamarase have been shown to be produced during shoot growth (Hughes, 1968; Collinge \& Hughes, 1982b; Dunn et al., 1988). The roots, flowers, seeds and seedlings before shoot emergence are not cyanogenic (Ware, 1925; Collinge \& Hughes, 1982b). The components of cyanogenesis are synthesized during leaf development and then stored in the mature leaf. Without tissue damage, the cyanoglucosides are only broken down during leaf senescence (Collinge \& 
Hughes, 1982b). Not all species have the same developmental profile, for example, in cassava the roots are cyanogenic and in flax and rubber cyanoglycosides are stored as disaccharides in the seed (Poulton, 1988).

Under normal growth conditions the tissues of a cyanogenic plant do not contain detectable HCN. This strongly suggests compartmentalization of the cyanoglucosides and the hydrolytic enzymes. Linamarase of white clover (Kakes, 1985) has been shown to be apoplastic and may be located in the epidermis. The tissue and subcellular localization of the cyanoglucosides in white clover are not known.

Some variation in the test reaction for $\mathrm{HCN}$ within a single plant was noted by Rogers \& Frykolm in 1937; the levels of $\mathrm{HCN}$ depending on the age of the leaf, the time of year and the size of the plant. The effect of the environment on cyanogenesis was studied by Collinge \& Hughes (1982b) who demonstrated a major effect of temperature on cyanoglucoside biosynthesis. This effect was not simple, plants differed both in their sensitivity to temperature changes and in the optimum temperature for synthesis. One plant varied from 0.85 $\mu$ moles of glucoside per milligram of protein at $18^{\circ} \mathrm{C}$ to undetected levels at $27^{\circ} \mathrm{C}$. Variation in the levels of $\mathrm{HCN}$ released during the growing season has been recorded by Askew (1933), Fraser \& Nowak (1988) and Vickery et al. (1987), who showed that meristem stress, low light intensity, cool temperature and inadequate phosphorus all favour high HCN levels. The mean effect of wilting was to increase $\mathrm{HCN}$ by 23 per cent on a dry weight basis.

\section{Genetics}

The inheritance of cyanogenesis in white clover was elucidated by a group working in New Zealand (Coop, 1940; Corkill, 1940; Melville and Doak, 1940; Corkill, 1942). Corkill (1942) showed that the inheritance of cyanogenesis in white clover is diploid. Acyanogenic white clover plants fall into three phenotypic classes; those which lack the cyanoglucosides, those which lack linamarase and those which lack both the cyanoglucosides and linamarase. The presence or absence of the two cyanoglucosides is determined by alleles at the locus, $A c$, whereas the presence or absence of linamarase is determined by alleles at the locus, $L i$. The cyanogenic phenotype requires the presence of a functional allele at both loci in the plant. The $A c$ and $L i$ loci segregate independently of each other.

A number of biochemical studies have been carried out to characterize the non-functional alleles at these loci. Incomplete dominance at the biochemical level has been demonstrated for both $A c$ and $L i$ (Hughes \&
Stirling, 1982; Maher \& Hughes, 1973), thus heterozygotes have intermediate levels of linamarase and cyanoglucosides.

Antibodies raised to purified linamarase have been used to quantify linamarase protein produced in plants of different genotype (Hughes et al., 1985). Plants homozygous for the recessive $l i$ allele contain no linamarase antigen, in addition li li plants produce no translatable linamarase mRNA (Dunn et al., 1988). Variant forms of white clover which produce reduced levels of linamarase activity have also been studied (Maher \& Hughes, 1973; Hughes et al., 1985). The reduced levels of linamarase activity are due to reduced rates of synthesis of the enzyme in developing leaves and have been shown to be determined by a genetic element which lies within 4 map units of the $L i$ locus (Hughes et al., 1985). Thus all the available evidence indicates that non-functional alleles at the $L i$ locus result in reduced or zero synthesis of linamarase and have characteristics of mutations in a cis-acting regulatory region.

White clover plants possessing only the nonfunctional ac alleles, are unable to synthesize either linamarin or lotaustralin from radiolabelled valine and isoleucine (Hughes \& Conn, 1976). In vivo and in vitro labelling experiments have shown that $a c$ ac plants have at least two steps in the converison of amino acid to hydroxynitrile missing from microsomal preparations (Hughes \& Conn, 1976; Collinge \& Hughes, 1982a). In vivo studies have suggested that the predicted soluble $\beta$-glucosyltransferase is also missing in ac ac plants (Hughes \& Conn, 1976).

There is considerable inherited variation in the level of cyanoglucoside produced in different plants. Analysis of cyanoglucoside levels in progeny from a fourgeneration backcross experiment has shown that most of the inherited variation is attributable to the existence of different functional $A c$ alleles in the parent plants (Hughes et al., 1984). No evidence for the presence in these plants of microsomes with different qualitative properties was found and the results were consistent with the production of different quantities of microsomes (Hughes et al., 1984).

There are several models for the nature of the $A c$ locus which would give rise to non-functional alleles with these characteristics. Thus the Ac locus may represent a number of linked structural genes for the cyanoglucoside biosynthetic pathway and the ac allele include mutations in at least three of these. An alternative model for the null $a c$ alleles is that they represent mutations in a sequence which controls the synthesis of the enzymes for cyanoglucoside biosynthesis. The existence of $A c$ alleles, which results in reduced levels of cyanoglucoside, suggests a controlling role for the 
locus. Furthermore, the intermediate levels in heterozygous $A c$ ac plants imply a cis-acting control function.

By carefully standardizing the Guiguard Picrate test for HCN, Corkill (1941) was able to identify high and low HCN-producing plants. The results of crossing plants giving different picrate reactions (Table 1) indicated that the level of $\mathrm{HCN}$ produced was inherited. Corkill interpreted these results to indicate the presence of modifying genes, however, the existence of different functional $A C$ alleles, the probable existence of different functional $L i$ alleles, and the intermediate $\mathrm{HCN}$ levels of heterozygotes, may account for these results.

Although the simple modified Mendelian dihybrid segregation ratios for alleles of the $A c$ and $L i$ loci are widely observed, some authors report aberrant ratios (e.g. Till, 1987). These are often observed when working with plants from wild populations rather than commercial cultivars and can sometimes be explained by the very low levels of HCN produced by some wild plants and the limits of detection of the tests used.

\section{Molecular genetics}

The biochemical difference between $L i L i$ and $l i l i$ plants has been used to select linamarase clones from white clover developing leaf cDNA libraries (Hughes et al., 1990). The identity of the clones was established using hybrid select translation and immunoprecipitation of the polypeptide product. The linamarase cDNA clones have been used in a number of studies. Northern blot analysis of mRNA shows that high levels of a 2.1 $\mathrm{kb}$ molecule are produced in $L i L i$ young leaves and very reduced levels seen in $l i l i$ leaves and $L i L i$ roots. Heterozygotes, ( $L i$ li) produced intermediate mRNA levels in young leaf tissue. The presence of low but measurable levels of linamarase homologous mRNA in

Table 1 The quantitative inheritance of $\mathrm{HCN}$ production (after Corkill, 1941)

\begin{tabular}{llrrrrrr}
\hline & \multicolumn{7}{c}{ Test reaction grade } \\
\cline { 2 - 8 } $\begin{array}{l}\text { Parents picrate } \\
\text { grade }\end{array}$ & 6 & 5 & 4 & 3 & 2 & 1 & 0 \\
\hline $2 \times 0$ & $\begin{array}{rrrrrrrr}0 \\
2 \times 0 \\
2 \times 3\end{array}$ & 0 & 0 & 3 & 8 & 1 & 17 \\
$3 \times 0$ & Number of \\
$3 \times 0$ & plants in \\
$3 \times 6$ & the progeny & 0 & 4 & 32 & 18 & 2 & 44 \\
$6 \times 0$ & 2 & 5 & 14 & 34 & 23 & 0 \\
$6 \times 0$ & 0 & 0 & 4 & 72 & 22 & 1 & 0 \\
$6 \times 3$ & 0 & 3 & 16 & 29 & 2 & 0 \\
11 & 6 & 3 & 4 & 9 & 0 & 0 \\
0 & 18 & 22 & 9 & 0 & 0 & 1 \\
7 & 38 & 3 & 1 & 0 & 0 & 0 \\
2 & 11 & 28 & 8 & 1 & 0 & 0 \\
\hline
\end{tabular}

li li leaves and $\mathrm{Li} L i$ roots conflicts with the zero levels of enzyme activity in these tissues. There are two possible explanations: firstly, both types of tissue contain low levels of an immunologically distinct noncyanogenic $\beta$-glucosidase (Hughes \& Dunn, 1982; Collinge \& Hughes, 1982a; Hughes et al., 1985; Kakes \& Eettink, 1985). Because small changes in the protein primary structure may result in major differences in the antigenic properties, it is possible for linamarase cDNA to show homology to a non-cyanogenic $\beta$-glucosidase mRNA produced at low levels in these tissues. An alternative explanation is that linamarase mRNA is produced at a low level in these tissues, which is detectable by Northern blot analysis but not at the protein level.

The cDNA clones have also been used to analyse genomic DNA using Southern blot analysis (Hughes et al., 1990). Considerable restriction fragment length polymorphism exists in white clover for genomic sequences homologous to linamarase cDNA (Hughes et al., 1988) (Fig. 3). This polymorphism has been used to analyse the genomic organization of these sequences in the Li Li plant used as a source of mRNA for cloning (Hughes et al., 1990). The studies show that the white clover genome contains three genes with homology to linamarase cDNA and that at least two of these genes segregate independently. Analysis of the co-segregation of linamarase activity and the presence of genomic restriction fragments identifies the genomic sequence specifying linamarase structure and indicates either a structural or cis-acting control function for the $L i$ locus.

The existence of a small multigene family for linamarase is a paradox given the single diploid locus for linamarase activity reported widely in the literature. One model for the $L i$ locus, which would be consistent with the data, is close linkage of the three structural genes. This is, however, refuted by the independent segregation of at least two of the genes. Two possible explanations for the paradox are, firstly, there may be inactive pseudogenes in the genome, and secondly, there may be homology between the linamarase gene and other $\beta$-glucosidase genes.

\section{Distribution}

Daday published two papers in 1954 (Daday, 1954a,b), which demonstrated a clear association between the frequency of cyanogenic morphs in natural populations of white clover and the mean January isotherm. The association is such that populations at higher altitudes and higher latitudes have lower frequencies of cyanogenic plants. The relationship between altitude and frequency of cyanogenic plants 
has been confirmed by Daday (1958) and a number of other workers (Table 2). In addition, Foulds \& Grime (1972) showed a decreasing frequency of $A c$ with conditions of soil moisture stress (drought). Linkage disequilibrium has been demonstrated for the $A c$ and $L i$ loci (Table 2), indicating that it is the production of $\mathrm{HCN}$ which is the important character in determining the distribution of the alleles of these loci and, in fact, most workers have assumed that the release of $\mathrm{HCN}$ is the selectively important phenotype. Although the pattern of distribution demonstrated by Daday has been confirmed, the low rate of seedling recruitment in undisturbed populations (Turkington et al., 1979) means that it is difficult to observe changes in gene frequencies in natural populations. In addition there is evidence that $T$. repens can show strong local specialization (Gliddon \& Trathan, 1985) and large differences in the local frequencies of $A c$ and $L i$ have been detected in The Netherlands (Kakes, 1987) which could not be attributed to January temperature differences.

\section{Selective forces}

A fundamental question concerning the cyanogenic polymorphism is whether the observed variation is
Fig. 3 Restriction fragment length polymorphism in white clover for sequences homologous to linamarase cDNA. Genotype Li Li track 1; genotype $L i$ li tracks, 2, 3, 7, 9, 10, 11, 12, 16, 18; genotype li li tracks 4, 5, 6, 8, 13, 14, 15, 17. Genomic DNA digested with Hind III and fragments separated on 0.8 per cent agarose, $\lambda$ Hind III molecular weight markers in kilobases.

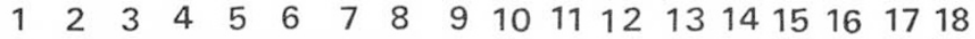

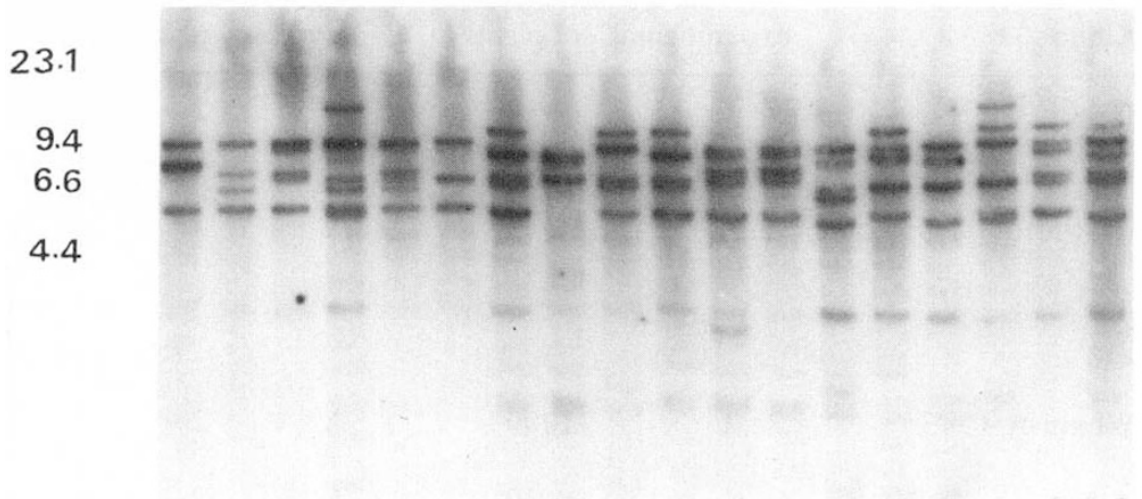

Table 2 Studies on distribution of cyanogenic phenotypes

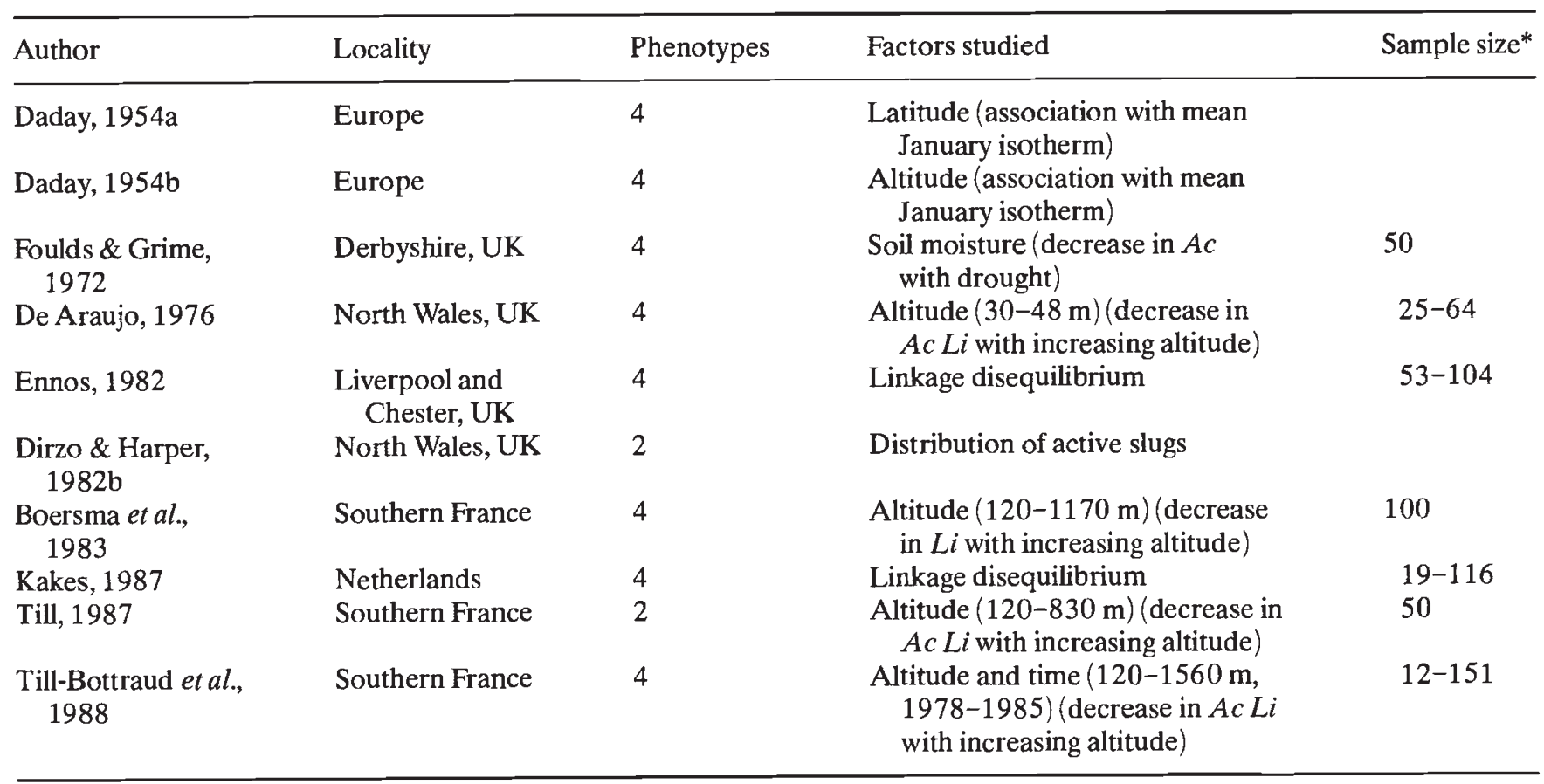

\footnotetext{
*Per site.
} 
neutral or is subject to selection. The role of cyanogenesis in plants has been widely discussed (Jones, 1981). The existence of the polymorphism argues against a role in primary metabolism and there is considerable evidence that $\mathrm{HCN}$, liberated during tissue damage by small grazing animals, acts as a feeding deterrent (Table 3). In particular, there are eight reports of selection against the acyanogenic morph by molluscs. In two studies (Dirzo \& Harper, 1982a; Kakes, 1989) it has been directly shown that both glucoside and hydrolytic enzyme are required for discriminatory feeding. However, the simple demonstration of selective grazing does not reveal the complexity of cyanogenesis as a plant defence reaction. Burgess \& Ennos (1987) have demonstrated that slugs taken from a site with a low frequency of cyanogenic morphs show a significantly greater degree of selective eating than slugs taken from a site with a high frequency of cyanogenic morphs. These results indicate that the selective advantage of the cyanogenic

Table 3 Studies on selection against acyanogenic phenotype by herbivores

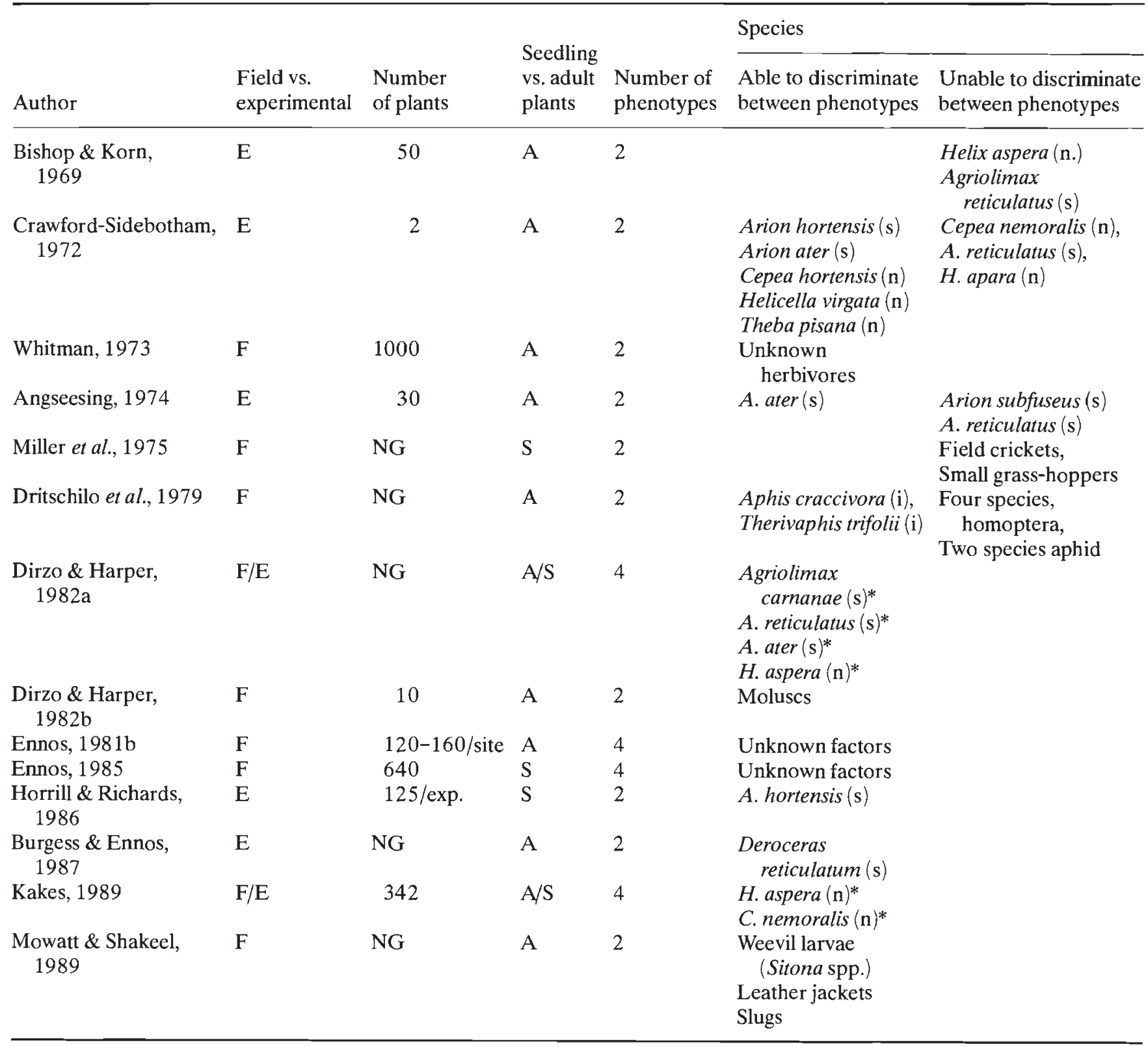

*Needs both glucoside and enzyme.

$\mathrm{F}=$ field trials; $\mathrm{E}=$ experimental data; $\mathrm{A}=$ adult $\mathrm{S}=$ seedling, $\mathrm{n}=$ snail $\mathrm{s}=$ slug; $\mathrm{i}=$ insect $\mathrm{NG}=$ not given. 
morph under grazing by the slug Deroceras reticulatum is likely to be frequency dependent.

Three groups of Lepidoptera (the Zygaenidea, Heliconiini and Acraeinae) feed selectively on plants containing cyanoglucosides (Raubenheimer, 1989). These insects release $\mathrm{HCN}$ when crushed and it has been shown (Nahrstedt \& Davis, 1986) that in Zygaena trifolii the chemical basis of cyanogenesis is the cyanoglucosides, linamarin and lotaustralin. Interestingly, $Z$. trifolii can both sequester these cyanoglucosides from the host plant and synthesize them de novo.

Clearly understanding selection in herbivore/plant systems also requires a study of the effect of the plant on the herbivore before a complete understanding can be achieved. Another indication of the complexity of cyanogenesis as a defence reaction is the demonstration by Lieberei et al. (1989) that cyanogenesis in the rubber tree inhibits the active defence reaction of the plant to a fungal pathogen (Microcyelus ulei).

The striking association between the frequency of cyanogenic plants and the mean January isotherm suggests that a balancing environmental factor selects against the cyanogenic morph thus maintaining the polymorphism in white clover. However, compared with selection against the acyanogenic morph, there are fewer experimental and field studies of possible balanc- ing selection and the results of these studies are equivocal (Paim \& Dean, 1975) (Table 4). The only character which has been noted by more than one author, and which may provide a selective advantage to the acyanogenic morph, is flowering. In fact Caradus $e t$ al. (1989), in a classification of 109 white clover cultivars, also notes a significant trend for the highly cyanogenic cultivars to flower earlier but have a lower maximum number of flowers. Daday (1965), in an experimental study, shows increased flower production of the ac li phenotype in cool conditions compared to the cyanogenic $(A c L i)$ phenotype. Experimental data which demonstrate a selective advantage of the acyanogenic morph, based on the 'metabolic costs' of cyanogenesis, do not exist, neither is there any convincing data to demonstrate a differential effect of frost damage on the two morphs, although both factors have been widely discussed in the literature.

Despite the early demonstration of inherited quantitative variation in HCN production by Corkill (1942) and the later biochemical studies (Hughes et al., 1984, 1985) very few of the ecological genetic studies of the cyanogenic polymorphism in white clover have examined $\mathrm{HCN}$ production quantitatively. Figure 4 (M. A. Hughes \& R. A. Ennos, unpublished) shows the levels of cyanoglucoside present in young leaves of

Table 4 Studies on selection for acyanogenic phenotype

\begin{tabular}{|c|c|c|c|c|c|c|}
\hline \multirow[b]{2}{*}{ Author } & \multirow[b]{2}{*}{$\begin{array}{l}\text { Field vs. } \\
\text { experimental }\end{array}$} & \multirow[b]{2}{*}{$\begin{array}{l}\text { Number } \\
\text { of plants }\end{array}$} & \multirow{2}{*}{$\begin{array}{l}\text { Seedling } \\
\text { vs. adult } \\
\text { plants }\end{array}$} & \multirow[b]{2}{*}{$\begin{array}{l}\text { Number of } \\
\text { phenotypes }\end{array}$} & \multicolumn{2}{|l|}{ Factors investigated } \\
\hline & & & & & Selection & $\begin{array}{l}\text { No } \\
\text { selection }\end{array}$ \\
\hline Daday, 1965 & $\mathrm{~F} / \mathrm{E}$ & $\begin{array}{l}325 \mathrm{~F} \\
28-81 \mathrm{E}\end{array}$ & A & 4 & $\begin{array}{l}\text { Flowering in } \\
\text { cool conditions }\end{array}$ & $\begin{array}{l}\text { Vegetative } \\
\text { growth }\end{array}$ \\
\hline $\begin{array}{l}\text { Foulds \& Young, } \\
1977\end{array}$ & $\mathrm{E}$ & 20 & A & 2 & & $\begin{array}{l}\text { Frost, drought } \\
\text { (respiration and } \\
\text { photosynthesis) }\end{array}$ \\
\hline $\begin{array}{l}\text { Wilkinson \& } \\
\quad \text { Millar, } 1978\end{array}$ & $\mathrm{E}$ & 4 & A & 4 & & $\begin{array}{l}\text { Stemphylium } \\
\text { sarciniforme } \\
\text { (pepper spot) }\end{array}$ \\
\hline $\begin{array}{l}\text { Dommee et al. } \\
\quad 1980\end{array}$ & $\mathrm{E}$ & 72 & A & 4 & Root growth & \\
\hline Ennos, 1981a & $\mathrm{E}$ & $39 \times 4$ & A & 4 & $\begin{array}{l}\text { Competition/ } \\
\text { interaction }(l i)\end{array}$ & Leaf size \\
\hline $\begin{array}{l}\text { Dirzo \& Harper, } \\
\text { 1982b }\end{array}$ & $\mathrm{F}$ & 10 & A & 2 & $\begin{array}{l}\text { Frost, flowering, } \\
\text { Uromyces trifolii } \\
\text { (rust) }\end{array}$ & \\
\hline Dirzo, 1984 & $\mathrm{~F}$ & NG & A & 2 & $\begin{array}{l}\text { Competition under } \\
\text { artificial grazing }\end{array}$ & \\
\hline $\begin{array}{l}\text { Jarvis \& Hatch } \\
1987\end{array}$ & $\mathrm{E}$ & 90 & $S$ & 2 & & Aluminium \\
\hline Kakes, 1989 & $\mathrm{~F} / \mathrm{E}$ & 342 & A & 4 & Flowering & \\
\hline
\end{tabular}

$\mathrm{F}=$ field trials; $\mathrm{E}=$ experimental data; $\mathrm{NG}$, not given; $\mathrm{A}=$ adult; $\mathrm{S}=$ seedling. 
plants taken from two populations collected from different altitudes and containing different proportions of cyanogenic plants. The plants were grown in the same environment for more than 12 months before leaf samples were taken. The number of heterozygous plants in each population is not known and can only be deduced from the Hardy-Weinberg equation. Thus the Cheviot population contains a higher proportion of heterozygous $(A c a c)$ plants, and this will contribute to the marked difference in cyanoglucoside levels between the two populations. Caradus et al. (1989) also found that high $\mathrm{HCN}$ potential was clearly associated with cultivars which have a high frequency of $A c$ $\mathrm{Li}$ phenotypes. In contrast, Boersma et al. (1983) examined levels of linamarase activity in plants taken from populations at three altitudes in Southern France $(800,1,000$ and $1,170 \mathrm{~m})$. Although considerable differences between plants in enzyme activity were shown, no difference between the two populations containing cyanogenic morphs was seen. However, one sample only contained four linamarase-positive plants.

Till (1987) studied four French populations (120, 170,600 and $830 \mathrm{~m}$ ) where the frequency of cyanogenic plants varied from 80 to 4 per cent. She found that the cyanogenic reaction, as measured by either the

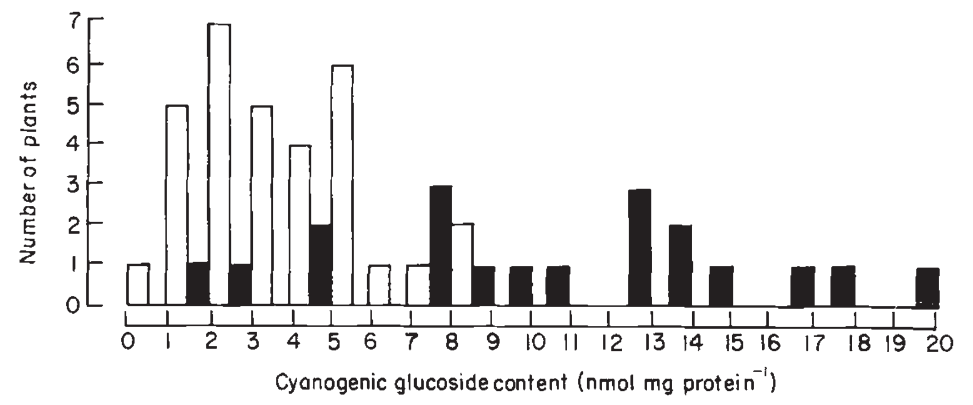

picrate or Feigl-Anger tests, was weak in populations $(600,830 \mathrm{~m})$ with low frequencies of cyanogenic plants. Furthermore, when different leaves of the same plant were tested, a proportion of the plants from these two populations showed both a positive and negative test reaction ('intraindividual heterogeneity'). This result is most easily explained by intraplant variation (Collinge \& Hughes, 1982b) reducing levels of glucoside or linamarase below the level of detection of the tests used. The phenomenon of 'Intraindividual heterogeneity' was most marked with the cyanoglucoside-only phenotype, as would be expected from this explanation. The heterogeneic phenotype was also shown to be inherited, consistent with the demonstration of inheritance of different levels of cyanoglucoside (Hughes et al., 1984).

\section{Evolution}

Several other species of Trifolium are cyanogenic (Table 5). These are all in the subsections Lotoidea and Platystylium of section Lotoidea of the genus Trifolium (Zohary \& Heller, 1984). In a survey of 31 species no other HCN-producing Trifolium species have been found (M. A. Hughes, unpublished observations).

Fig. 4 Comparison of cyanogenic glucoside content of plants from a lowland ( $\bullet$ Tooting $61 \mathrm{~m})$ and an upland population ( $\square$ Cheviot $610 \mathrm{~m}$ ) of white clover. The cyanoglucoside content of young leaves was measured colorimetrically using the method of Hughes et al. (1984). All plants had the glucoside only phenotype $(A c l i)$ and were selected using the picrate test (Corkill, 1940).

Table 5 Classification of Trifolium species for cyanogenesis

\begin{tabular}{|c|c|c|c|c|c|}
\hline \multirow[b]{2}{*}{ Species } & \multirow[b]{2}{*}{$2 n$} & \multicolumn{2}{|c|}{$\begin{array}{l}\text { Presence of } \\
\text { glucoside }\end{array}$} & \multicolumn{2}{|c|}{$\begin{array}{l}\text { Presence of } \\
\text { hydrolytic enzymes }\end{array}$} \\
\hline & & & Gibson et al.* & & Gibson et al.* \\
\hline T. uniflorum $\ddagger$ & 32 & $\mathrm{~N}$ & $+\S$ & $\mathrm{N}$ & 0 \\
\hline T. nigrescens $\nmid$ & 16 & + & + & + & + \\
\hline T. isthmocarpum & 16 & + & + & $\mathrm{P}$ & + \\
\hline T. montanum & 16 & 0 & $\mathrm{P}$ & 0 & 0 \\
\hline T. ambiguum & $16,32,48$ & + & $\mathrm{P}$ & 0 & 0 \\
\hline T. repens & 32 & $\mathbf{P}$ & $\mathrm{P}$ & $\mathrm{P}$ & $\mathrm{P}$ \\
\hline T. occidentale $\ddagger$ & 16 & + & + & 0 & 0 \\
\hline
\end{tabular}

*Gibson et al., 1972.

$\dagger$ Includes subspecies petrisavii and meneghinianium.

$\ddagger$ Species hybridized with $T$. repens.

$\S$ Trace amounts; $\mathrm{N}=$ not tested; $\mathrm{P}=$ polymorphic. 
Three species ( $T$. ambiguum, T. isthmocarpum, $T$. montanum) have been shown to be polymorphic for either the presence of the glucoside or the hydrolytic enzyme. It is likely that all reports of the glucoside-only phenotype in a species, for example in T. occidentale, indicate polymorphism for the cyanogenic character, particularly given the small number of plants tested by each author. All the species that have been hybridized with T. repens (Chen \& Gibson, 1972; Gibson et al., 1972) are cyanogenic but there are three additional cyanogenic species not known to hybridize with $T$. repens. The $T$. repens linamarase $\mathrm{cDNA}$ clone has been shown (M. A. Hughes \& T. Carron, unpublished data) to have homology to genomic sequences in $T$. nigrescens and $T$. isthmocarpum. It would be interesting to know the relationship of the linamarase genes in these species, as this may provide valuable information on speciation in the genus. The taxonomic significance of cyanogenesis in the genus Lotononis (Leguminosae) has been discussed by Van Wyk (1989). In this genus basic groups are either cyanogenic or acyanogenic but some groups contain both cyanogenic and acyanogenic species. This feature of the distribution of cyanogenesis in Lotononis is similar to the pattern seen in Trifolium. As the ability to produce $\mathrm{HCN}$ is correlated with morphological variation, further genetic and molecular information may provide evidence for the infrageneric classification of Trifolium.

\section{Conclusion}

The genetic units that control the cyanogenic polymorphism in white clover are complex and provide a model system for the study of the organization and control of plant genes which determine this type of metabolic process. The biochemical characterization of null alleles of both the $A c$ and $L i$ locus is not complete, in particular the possible control of oxynitrilase activity by the $L i$ locus is unknown and the individual proteins involved in cyanoglucoside biosynthesis have not been characterized. Using the polymorphism in a combination of molecular and genetic studies will elucidate fundamental information about the nature of these loci and the processes that they control.

The relationship between altitude and the distribution of the cyanogenic morph is clearly established, but many questions about the environmental and biological factors which determine this pattern of distribution are unresolved. The discriminatory feeding of moluscs on acyanogenic plants is well established, however, despite a considerable amount of research, there is no convincing consensus demonstration of any factor which selects against the acyanogenic morph. It is clear from the data shown in Figs 3 and 4 that there is con- siderable variation in the cyanogenic system of white clover which is not described by the simple test for the presence versus absence of $\mathrm{HCN}$ commonly used to detect and study the polymorphism. It is unlikely that a complete understanding of the distribution and maintenance of the cyanogenic polymorphism will be elucidated without consideration of the quantitative variation in $\mathrm{HCN}$ production. In addition, the ability to detect allelic differences at the DNA level, using restriction fragment polymorphisms, will provide further insight into the relationships of particular alleles and the ecogenetics of each cyanogenic morph. A combination of ecogenetic and molecular studies may also resolve one unexplained feature of the genetic control of the cyanogenic polymorphism, namely the independent assortment of the $L i$ and $A c$ loci.

\section{References}

ANGSEeING, J. A. P. 1974. Selective eating of the acyanogenic form of Trifolium repens. Heredity, 32, 73-83.

ARMSTRONG, H. E., ARMSTRONG, E. F. AND HORTON, E. 1913. Herbage studies II - Variation in Lotus corniculatus and Trifolium repens (cyanophoric plants). Roy. Soc. (Lond.) Proc. B, 86, 262-269.

ASKEW, H. O. 1933. Determination of hydrocyanic acid in white clover. NZ J. Sci. Technol. B, 14, 359-365.

BISHOP, J. A. AND KORN, M. E. 1969. Natural selection and cyanogenesis in white clover, Trifolium repens. Heredity, 24, 423-430.

BOERSMA, P., KAKES, P. AND SCHRAM, A. W. 1983. Linamarase and $\beta$-glucosidase activity in natural populations of Trifolium repens. Acta. Bot. Neerl., 32, 39-47.

BURGESS, R. S. L. AND ENNOS, R. A. 1987. Selective grazing of acyanogenic white clover: Variation in behaviour among populations of the slug Deroceras reticulatum. Oecologia, 73, 432-435.

CARADUS, J. R., MACKAY, A. C., WOODFIELD, D. R., VAN DEN BOSCH, J. AND WEWALA, S. 1989. Classification of a world collection of white clover cultivars. Euphytica, 42, 183-196.

CARVALho, F. J. P. DE C. 1981. Ph.D. Dissertation, University of California, Davis, CA, USA.

CHEN, C-C. AND GIBSON, P. B. 1972. Chromosome relationships of Trifolium uniflorum to $T$. repens and T. occidentale. Can.J. Genet. Cytol., 14, 591-595.

COLLINGE, D. B. AND HugHES, M. A. 1982a. In vitro characterisation of the $A c$ locus in white clover (Trifolium repens $\mathbf{L}$.). Arch. Biochem. Biophys., 218, 38-45.

COLLINGE, D. B. AND HUGHES, M. A. 1982 b. Developmental and physiological studies on the cyanogenic glucosides of white clover (Trifolium repens L.). J. Exp. Bot., 33, 154-161.

COLLINGE, D. B. AND Hughes, M. A. 1984. Evidence that linamarin and lotaustralin, the two cyanogenic glucosides of Trifolium repens $\mathbf{L}$., are synthesised by a single set of microsomal enzymes controlled by the Ac/ac locus. Plant Sci. Lett., 34, 119-125. 
COOP, I. E. 1940. Cyanogenesis in white clover III Study of linamarase. NZ J. Sci. Technol. B, 22-23, 71-83.

CORKILl, L. 1940. Cyanogenesis in white clover I Cyanogenesis in single plants. NZ J. Sci. Technol. B, 22-23, 65-67.

CORKILL, L. 1942. Cyanogenesis in white clover (Trifolium repens L.) V. The inheritance of cyanogenesis. NZ J. Sci. Technol. B, 23, 178-193.

CRAWFORD-SIDEBOTHOM, T. J. 1972. The role of slugs and snails in the maintenance of the cyanogenesis polymorphisms of Lotus corniculatus and Trifolium repens. Heredity, 28, 405-411.

DADAY, H. 1954a. Gene frequencies in wild populations of Trifolium repens I. Distribution by altitude. Heredity, $\mathbf{8}$, $61-78$.

DADAY, H. 1954b. Gene frequencies in wild populations of Trifolium repens II. Distribution by altitude. Heredity, $\mathbf{8}$, 377-384.

DADAY, H. 1958. Gene frequencies in wild populations of Trifolium repens III. World distribution. Heredity, 12, 169-184.

DADAY, H. 1965. Gene frequencies in wild populations of Trifolium repens L. IV. Mechanism of natural selection. Heredity, 20, 355-365.

DE ARAUJO, A. M. 1976. The relationship between altitude and cyanogenesis in white clover (Trifolium repens L.) Heredity, 37, 291-293.

DIRZo, R. 1984. Herbivory: A phytocentric view in perspectives. In: Dirzo, R. and Sarukhan, J. (eds) Plant Population Ecology, Sinauer, USA, pp. 141-156.

DIRZO, R. AND HARPER, J. L. 1982a. Experimental studies on slug-plant interactions III. Differences in the acceptability of individual plants of Trifolium repens to slugs and snails. J. Ecol., 70, 101-117.

DIRZO, R. AND HARPER, J. L. 1982b. Experimental studies on slug-plant interactions IV. The performance of cyanogenic and acyanogenic morphs of Trifolium repens in the field. J. Ecol., 70, 119-138.

DOMMEE, B., BREAKFIELD, P. M. AND MACNAIR, M. R. 1980. Differential root growth of the cyanogenic phenotypes of Trifolium repens L. Oecol. Plant., 1, 367-370.

DRITSCHILO, W., KRUMMEL, J., NAFUS, D. AND PIMENTEL, D. 1979. Herbivorous insects colonising cyanogenic and acyanogenic Trifolium repens. Heredity, 42, 49-56.

DUNN, M. A., HUGHES, M. A. AND SHARIF, A. L. 1988. Synthesis of the cyanogenic $\beta$-glucosidase, linamarase, in white clover. Arch. Biochem. Biophys., 243, 361-373.

ENNOS, R. A. 1981a. Manifold effects of the cyanogenic loci in white clover. Heredity, 46, 127-132.

ENNOS, R. A. 1981b. Detection of selection in populations of white clover (Trifolium repens L.). Biol. J. Linn. Soc., 15, 75-82.

ENNOS, R. A. 1982. Association of the cyanogenic loci in white clover. Genet. Res., 40, 65-72.

ENNOS, R. A. 1985. Measuring the effects of genetic variation of plant fitness. In: Haeck, J. and Woldendorp, J. P. (eds) Structure and Functioning of Plant Populations, NorthHolland Publishing Co., Amsterdam, pp. 153-160.
FOULDS, W. AND GRIME, J. P. 1972. The influence of soil moisture on the frequency of cyanogenic plants in populations of Trifolium repens and Lotus corniculatus. Heredity, 28, 143-146.

FOULDS, w. AND YOUNG, L. 1977. Effect of frosting, moisture stress and potassium cyanide on the metabolism of cyanogenic and acyanogenic phenotypes of Lotus corniculatus L. and Trifolium repens L. Heredity, 38, 19-24.

FRAZER, J. AND NOWAK, J. 1988. Studies on variability in white clover: Growth habits and cyanogenic glucosides. Ann. Bot., 61, 311-318.

GIBSON, P. B., BARNETT, O. W. AND GILlinghAM, J. T. 1972. Cyanoglucoside and hydrolysing enzyme in species related to Trifolium repens. Crop Sci., 12, 708-709.

GLIDDON, C. AND TRATHAN, P. 1985. Interactions between white clover and perennial ryegrass in an old permanent pasture. In: Haeck, J. and Woldendorp, J. W. (eds) Structure and Functioning of Plant Populations, North-Holland Publishing Co., Amsterdam, pp. 161-169.

HAHLBROCK, K. AND CONN, E. E. 1971. Evidence for the formation of linamarin and lotaustralin in flax seedlings by the same glucosyltransferase. Phytochemistry, 10, 10191023.

HALKIER, B. A., OLSEN. C.-E. AND MOLLER, B. L. 1989. The biosynthesis of cyanogenic glucosides in higher plants J. Biol. Chem., 264, 19487-19494.

HORRILL, J. C. AND RICHARDS, J. A. 1986. Differential grazing by the mollusc Arion hortensis Fer. on cyanogenic and acyanogenic seedlings of the white clover, Trifolium repens L. Heredity, 56, 277-281.

HUGHES, M. A. 1968. Studies on the $\beta$-glucosidase system of Trifolium repens L. J. Exp. Bot., 19, 427-434.

HUGHES, M. A. AND CONN, E. E. 1976. Cyanoglucoside biosynthesis in white clover (Trifolium repens L.). Phytochemistry, 15, 687-701.

HUGHES, M. A. AND DUNN, M. A. 1982. Biochemical characterisation of the $L i$ locus, which controls the activity of the cyanogenic $\beta$-glucosidase in Trifolium repens L. Plant Mol. Biol., 1, 169-181.

HUGHES, M. A., DUNN, M. A. AND PEARSON, J. R. 1985. A regulatory element controlling the synthesis of the cyanogenic $\beta$ glucosidase (linamarase) of white clover. Heredity, 55, 387-391.

HUGHeS, M. A., SHARIF, A. L., DUNN, M. A. AND OXTOBY, E. 1988. The molecular biology of cyanogenesis. In: Cyanide Compounds in Biology. CIBA Foundation Symposium 140, J. Wiley \& Sons, Chichester, pp. 111-130.

HUGHES, M. A., SHARIF, A. L., DUNN, M. A., OXTOBY, E. AND PANCORO, A. 1990. Restriction fragment length polymorphism segregation analysis of the $L i$ locus in Trifolium repens $\mathrm{L}$. Plant Mol. Biol., 14, 407-414.

HUGHES, M. A. AND STIRLING, J. D. 1982. A study of dominance at the locus controlling cyanoglucoside production in Trifolium repens L. Euphytica, 31, 477-483.

hughes, M. A., STIRling, J. D. AND COLlinge, D. B. 1984. The inheritance of cyanoglucoside content in Trifolium repens L. Biochem. Genet., 22, 139-151.

JARVIS, S. S. AND HATCH, D. J. 1987. Differential effects of low 
concentration of aluminium on the growth of four genotypes of white clover. Plant Soil, 99, 241-253.

JONES, D. A. 1981. Cyanide and coevolution. In: Vennesland, B., Conn, E. E., Knowles, C. J., Westley, J. and Wissing, F. (eds) Cyanide and Biology, Academic Press, New York, pp. 509-516.

KAKES, P. 1985. Linamarase and other $\beta$-glucosidases are present in the cell walls of Trifolium repens $\mathrm{L}$. leaves. Planta, 166, 156-160.

KAKES, P. 1987. On the polymorphisms for cyanogenesis in natural populations of Trifolium repens $\mathrm{L}$. in the Netherlands I. Distribution of the genes Ac and Li. Acta. Bot. Neerl., 36, 59-69.

KAKES, P. 1989. An analysis of the costs and benefits of the cyanogenic system in Trifolium repens. Theoret. Appl. Genet., 77, 111-118.

KAKES, P. AND EELTINK, H. 1985. The presence of a specialised $\beta$-glucosidase, linamarase, in the leaves of Trifolium repens $\mathrm{L}$. is controlled by the gene Li. Z. Naturforsch. Sect. C Biosci., 40, 509-513.

LIEBEREI, R., BIEHL, B., GIESEMANN, A. AND JUNQUEIRA, N. T. V. 1989. Cyanogenesis inhibits active defence reactions in plants. Plant Physiol., 90, 33-36.

MAHER, E. P. AND HUGHES, M. A. 1973. Studies on the nature of the $L i$ locus in white clover II. The effects of genotype on enzyme activity and properties. Biochem. Genet., 8, 13-26.

MELVILLE, J. AND DOAK, B. W. 1940. Cyanogenesis in white clover II. Isolation of the glucoside constituents. NZ J. Sci. Technol. B, 22, 67-70.

MILLER, J. D., GIBSON, P. B., COPE, W. A. AND KNIGHT, E. E. 1975. Herbivore feeding on cyanogenic and acyanogenic white clover seedlings. Crop Sci., 15, 90-91.

MIRANDE, M. 1912. Sur la presence de l'acide cyanohydrique dans le trefle rampant (Trifolium repens L.). Compt Rend. Acad. Sci. (Paris), 155, 651-653.

MOWAT, D. J. AND SHAKEEL, M. A. 1989. The effect of different cultivars of clover on numbers of, and leaf damage by, some invertebrate species. Grass Forage Sci., 44, 11-18.

NAHRSTEDT, A. AND DAVIS, R. H. 1986. Uptake of linamarin and lotaustralin from their food plant by larvae of Zygaena trifolii. Phytochemistry, 25, 2299-2302.

PAIM, N. R. AND DEAN, C. E. 1975. Characteristics of cyanogenic and acyanogenic white clover plants. Soil Crop Sci. Soc.
Forida Proc., 35, 18-21.

POCSI, I., KISS, L., HUGHES, M. A. AND NANASI, P. 1989. Kinetic investigation of the substrate specificity of the cyanogenic $\beta$-D-glucosidase of white clover. Arch. Biochem. Biophys., 272, 496-506.

POULTON, J. E. 1988. Localisation and catabolism of cyanogenic glycosides. In: Cyanide Compounds in Biology, CIBA Foundation Symposium 140, J. Wiley \& Sons, Chichester, pp. 67-91.

RAUBENHEIMER, D. 1989. Cyanoglucoside gynocardin from Acraea horta L. J. Chem. Ecol., 15, 2177-2189.

ROGERS, C. F. AND FRYKOLM, O. C. 1937. Observations on the variations in cyanogenic power of white clover plants. $J$. Agric. Res., 55, 533-537.

SELMAR, D., LEIBEREI, R., BIEHL, B. AND CONN, E. E. 1989. $\alpha-$ Hydroxynitrile lyase in Hevea brasiliensis and its significance for rapid cyanogenesis. Physiol. Plant, 75, 97-101.

TILL, I. 1987. Variability of expression of cyanogenesis in white clover (Trifolium repens L.). Heredity, 59, 265-271.

TILL-BOTTRAUD, I., KAKES, P. AND DOMMEE, B. 1988. Variable phenotypes and stable distribution of the cyanotypes of Trifolium repens L. in Southern France. Acya Oecologica, 9, 393-404.

TURKINGTON, R., CHAN, M. A., VARDY, A. AND HARPER, J. L. 1979 The growth, distribution and neighbourhood relationships of $T$. repens in a permanent pasture III. The establishment and growth of $T$. repens in natural and perturbed sites. $J$. Ecol., 67, 231-243.

VAN WYK, B-E. 1989. The taxonomic significance of cyanogenesis in Lotononis and related genera. Biochem. Syst. Ecol., 17, 297-303.

VICKERY, P. J., WHEELER, J. L. AND MULCAHY, C. 1987. Factors affecting the hydrogen cyanide potential of white clover (Trifolium repens L.). Aust. J. Agric. Res., 38, 1053-1059.

WARE, W. M. 1925. Experiments and observations on forms and strains of Trifolium repens L. J. Agri. Sci., 15, 47-50.

WHITMAN, R. J. 1973. Herbivore feeding and cyanogenesis in Trifolium repens $\mathrm{L}$. Heredity, 30, 241-245.

WILKINSON, H. T. AND MILlAR, R. L. 1978. Cyanogenic potential of Trifolium repens $\mathrm{L}$. in relation to pepper spot caused by Stemphylium sarciniforme. Can. J. Bot., 56, 2491-2496.

zOHARY, M. AND HELleR, D. 1984. The Genus Trifolium. Israel Academy of Science, Jerusalem. 